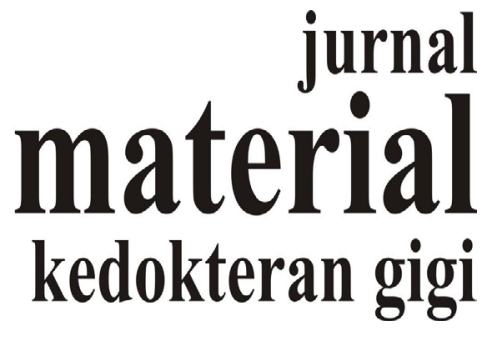

p-ISSN 2302-5271 e-ISSN 2685-0214

DOI 10.32793/jmkg.v8i1.302

\title{
Pengaruh Lama Perendaman E-Glass Fiber Reinforced Composite Dalam Obat Kumur Terhadap Kekuatan Fleksural
}

\author{
Hasna Syifa Yuniva, Widowati Siswomihardjo, Siti \\ Sunarintyas \\ Departemen Ilmu Biomaterial Kedokteran Gigi \\ Fakultas Kedokteran Gigi Universitas Gadjah Mada \\ Yogyakarta, Indonesia
}

\section{ABSTRAK}

Fiber reinforced composite (FRC) merupakan bahan yang terdiri dari resin komposit (matriks), fiber ()reinforced dan silane (meningkatkan kekuatan adhesi). Fiber reinforced composite dapat digunakan sebagai kerangka crown. Banyak masyarakat menggunakan obat kumur untuk menjaga kebersihan rongga mulut. Penelitian ini bertujuan mengetahui pengaruh lama perendaman E- glass FRC dalam obat kumur terhadap kekuatan fleksural.

Bahan penelitian adalah E-glass (Fiber Splint Polydentia Multi Layer, Swiss), resin komposit (Master Flow Biodinamica, Brazil), silane (Monobond ivoclar vivadent) dan obat kumur (Listerine $\circledR$ Multi Protect). Spesimen berbentuk balok $(25 \times 2 \times 2)$ $\mathrm{mm}$ berjumlah 12 . Spesimen dibagi menjadi 3 kelompok K1 kelompok kontrol dan K2 dan K3 kelompok perlakuan (perendaman 24 dan 48 jam) Nilai kekuatan fleksural diukur dengan universal testing mechine (Pearson, Texas). Data yang diperoleh dianalisis menggunakan one way anova dilanjutkan uji LSD.

Hasil penelitian menunjukkan penuruan rerata kekuatan fleksural dari K1, K2 dan K3. Hasil uji one way anova menunjukkan terdapat pengaruh yang bermakna karena signifikansi lebih dari 0,05 pada lama perendaman E-glass FRC dalam obat kumur terhadap kekuatan fleksural. Hasil uji LSD menunjukkan perbedaan bermakna signifikan antar semua kelompok perlakuan. Kesimpulan penelitian ini adalah lama perendaman E-glass FRC dalam obat kumur menurunkan kekuatan fleksural E-glass FRC.

Kata kunci: FRC, E-glass, lama perendaman, obat kumur, alkohol, Listerine, kekuatan fleksural.

The Duration of E-Glass Fiber Reinforced Composite Immersion Into The Moutwash Againts The Flexural Strength

Korespondensi:

Hasna Syifa Yuniva

Email:hasna.syifa.y@mail.ugm.ac.id

\section{ABSTRACT}

Fiber reinforced composite (FRC) is a material consisting of a composite resin (matrix), fiber (reinforced) and silanes 
(to improve the adhesion strength). FRC can be used as a crown framework. More people used mouthwash for oral hygient. The objective of this study was to know the effect of the duration of E-glass FRC immersion into the mouthwash against the flexural strength.

The research materials were E-glass (Fiber Splint Polydentia Multi-Layer, Switzerland), composite resin (Master Flow Biodynamic, Brazil), silane (Monobond Ivoclar Vivadent) and mouthwash (Listerine $\AA$ Multi Protect). Twelve the beam-shaped specimens $(25 \times 2 \times 2) \mathrm{mm}$ The specimens were divided into 3 groups: $\mathrm{K} 1$ control group (was not immersed) $\mathrm{K} 2$ and $\mathrm{K} 3$ treatment groups (was immersed for 24 and 48 hours). The flexural strength value was measured using a universal testing machine (Pearson, Texas). The data were analyzed using oneway ANOVA followed-up by LSD.

The results showed decrease of the average flexural strengths of mouthwash $\mathrm{K} 1$, $\mathrm{K} 2$ and $\mathrm{K} 3$. The one-way ANOVA test results showed that there was a significant $\mathrm{P}>0.05$ in the duration of E-glass FRC immersion into the mouthwash against the flexural strength. The LSD test results showed significant differences between all treatment groups. The conclusion of this study is that the duration of E-glass FRC immersion into mouthwash will lower the strength of flexural E-glass FRC.

Keywords: FRC, E-glass, duration of immersion, mouthwash, alcohol, Listerine, flexural strength.

\section{PENDAHULUAN}

Fiber reinforced composite (FRC) merupakan bahan yang terdiri dari komposit sebagai matriks, fiber sebagai bahan reinforced ${ }^{1}$ dan selain matriks dan fiber terdapat komponen lain yaitu coupling agent. ${ }^{4}$ Coupling agent mampu meningkatkan kekuatan adhesi antara matriks dan fiber. $^{5}$ Fiber mampu memberi kekuatan dan kekakuan, selain itu matriks polimer sebagai pendukung polimer fiber yang akan memberikan workability FRC. ${ }^{4}$ Fiber didefinisikan sebagai bahan yang memanjang, berikatan secara melintang sama disemua arah, dan ketebalan kurang dari $250 \mu \mathrm{m}$. Fiber reinforced composite yaitu memiliki kekuatan tensil, fatigue, modulus fleksural yang tinggi, anisotropic dan toleransi pada kerusakan fatigue. ${ }^{10}$

Tipe fiber yang sering digunakan di dunia kedokteran gigi adalah fiber jenis glass, PE (poliethylene), poliester, carbon/ graphite(C/G), aramid, quartz, dan ceramic fiber. Karakteristik Glass merupakan untaian tipis dengan dasar silika, $\mathrm{SiO}_{2}$ atau formula glass lain. Tipe glass yang biasa digunakan adalah E-glass dan S-glass. Jenis E-glass (E berarti elektrik) dibuat dari aluminoborosilikat glass dengan kurang dari 1 wt\% alkali oxide. Komponen bahan kimia E-glass adalah $\mathrm{SiO}_{2}$ 54 wt\%, $\mathrm{Al}_{2} \mathrm{O}_{3} 14 \mathrm{wt} \%, \mathrm{CaO}+\mathrm{MgO} 22$ wt\%, $\mathrm{B}_{2} \mathrm{O}_{3} \quad 10$ wt\% and $\mathrm{Na}_{2} \mathrm{O}+\mathrm{K}_{2} \mathrm{O}$ less than 2 wt\%. ${ }^{10}$

Obat kumur mengandung air, agen antimikroba, garam, dan alkohol. Perbedaan konsentrasi dapat mempengaruhi $\mathrm{pH}$ di dalam obat kumur. ${ }^{7}$ Obat kumur dapat mencegah karies, mengontrol karies dan penyakit periodontal. ${ }^{9}$ Alkohol mampu mendegradasi resin komposit, dengan melemahkan matriks polimer dengan meningkatkan ketidakreaktifan monomer dan oligomer yang berdifusi keluar material. Selanjutnya dapat mempengaruhi kekerasan, penyerapan dan bahan pelarut pada resin komposit. Alkohol menyebabkan polimer pada permukaan resin menjadi terpisah dan menyebabkan keretakan kecil. Semakin lama perendaman maka akan semakin banyak partikel larutan yang masuk kedalam ruang mikroporositas resin dan mengurangi kekuatan pada resin. Kekuatan fleksural atau kekuatan transversal merupakan suatu daya tahan benda terhadap beban yang diterima. Adanya pengujian kekuatan transversal diasumsikan sebagai ketahanan benda selama menerima tekanan pengunyahan. $^{8}$ Penelitian ini bertujuan mengetahui pengaruh lama perendaman E- glass FRC dalam obat kumur terhadap kekuatan fleksural.

\section{METODE PENELITIAN}

Penelitian ini menggunakan bahan yang terdiri dari E-glass (Fiber Splint Polydentia Multi Layer, Swiss), resin komposit 
(Master Flow Biodinamica, Brazil), silane (Monobond ivoclar vivadent) dan obat kumur (Listerine $\AA$ ). Sampel dibuat dengan bentuk balok berukuran $25 \times 2 \times 2 \mathrm{~mm}$ menggunakan brass mould (Gambar 1 ). Terdapat 3 kelompok yang akan diuji dan setiap kelompok 4 sampel. Kelompok pertama tidak direndam dalam obat kumur, kelompok kedua direndam di dalam obat kumur selama 24 jam dengan suhu $37^{\circ} \mathrm{C}$, dan kelompok ketiga direndam di dalam obat kumur selama 48 jam dengan suhu $37^{\circ} \mathrm{C}$. Spesimen diberikan beban $50 \mathrm{~N} /$ menit dan jarak $20 \mathrm{~mm}$ antara dua rentang sesuai dengan ISO 10477: 92.

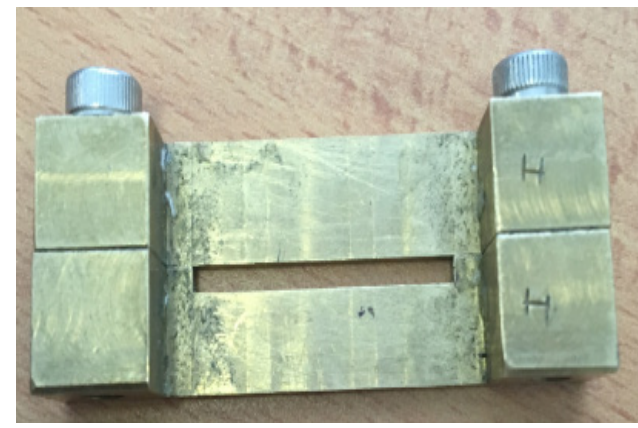

Gambar. 8. Cetakan untuk pembuatan sampel pada pengukuran kekuatan fleksural.

\section{HASIL PENELITIAN}

Pengajuan pengaruh lama perendaman E-glass fiber reinforced composite dalam obat kumur terhadap kekuatan fleksural dilakukan di Laboratorium Riset Terpadu Fakultas Kedokteran Gigi Universitas Gadjah Mada dan Laboratorium Bahan Jurusan Teknik Mesin Fakultas Teknik Universitas Gadjah Mada. Uji fleksural dilakukan dengan menggunakan alat universal testing mechine metode three point bending. Hasil rerata dari penelitian kekuatan fleksural FRC dapat dilihat pada tabel 1 .

Tabel 1. Hasil rerata dan simpangan baku kekuatan fleksural (MPa) FRC setelah perendaman 0 jam, 24 jam dan 48 jam dalam obat kumur

\begin{tabular}{|llc|}
\hline Kelompok Fiber & $\mathrm{N}$ & Rerata \pm Simpangan Baku \\
\hline $\mathrm{K}_{1}$ & 4 & $120,2 \pm 3,9$ \\
$\mathrm{~K}_{2}$ & 4 & $116,7 \pm 9,5$ \\
$\mathrm{~K}_{3}$ & 4 & $85,1 \pm 9,3$ \\
\hline
\end{tabular}

Tabel 1. Menunjukan adanya perubahan kekuatan fleksural dari hasil perendaman E-glass fiber reinforced composite yaitu pada perendaman 0 jam memiliki nilai rerata kekuatan fleksural tertinggi yang diikuti oleh perendaman 24 jam dan 48 jam. Uji one way anova digunakan untuk mengetahui adanya pengaruh perendaman dalam obat kumur terhadap kekuatan fleksural pada tiga kelompok, tetapi sebelumnya dilakukan uji normalitas dan homogenitas untuk mengetahui apakah data penelitian terdistribusi normal dan homogen. Uji normalitas yang digunakan adalah SaphiroWilk karena jumlah sampel tidak lebih dari $50^{2}$

Tabel 2. Hasil Uji one way anova kekuatan fleksural FRC setelah direndam 0 jam, 24 jam dan 48 jam dalam obat kumur

\begin{tabular}{|lcc|}
\hline & Derajat Bebas & Signifikansi \\
\hline Antar Kelompok & 2 & 0,001 \\
Dalam Kelompok & 9 & \\
Total & 11 & \\
\hline
\end{tabular}

Hasil Uji one way anova kekuatan fleksural FRC menunjukkan signifikansi 0,001 yang berarti lama perendaman E-glass FRC berpengaruh secara bermakna menurunkan kekuatan fleksural karena nilai signifikansi lebih dari 0,05. Selanjutnya dilakukan uji Post-Hoc menggunakan least significance different (LSD) untuk mengetahui perbedaan yang bermakna dari rerata kekuatan fleksural antar kelompok perendaman. Hasil uji LSD dapat dilihat pada tabel 3 .

Tabel 3. Hasil uji LSD kekuatan fleksural FRC setelah direndam 0 jam, 24 jam dan 48 jam dalam obat kumur

\begin{tabular}{|lcc|}
\hline Lama Perendeman & Perbedaan Rerata & Signifikansi \\
\hline $\mathrm{K}_{1}$ & $17,6250^{*}$ & 0,025 \\
$\mathrm{~K}_{2}$ & $34,1500^{*}$ & 0,001 \\
$\mathrm{~K}_{3}$ & $16,5250^{*}$ & 0,024 \\
\hline
\end{tabular}

Keterangan: Tanda $(*)$ menunjukkan nilai signifikan $(p<0,05)$

Hasil uji LSD kekuatan fleksural FRC menunjukan perbedaan bermakna $(p<0,05)$ antara rerata kekuatan fleksural pada 
perendaman 0 jam dengan kelompok yang dilakukan perendaman selama 24 jam, kelompok yang dilakukan perendaman 0 jam dengan kelompok yang dilakukan perendaman selama 48 jam, dan pada kelompok yang dilakukan perendaman selama 24 jam dan 48 jam.

Penurunan kekuatan fleksural pada perendaman 48 jam jauh lebih besar dibandingkan perendaman 0 jam, karena selain pada perendaman 48 jam yang mengandung alkohol dan air, juga dipengaruhi oleh lama ya penyerapan alkohol $^{3}$ dan penyerapan air. ${ }^{6}$ Penurunan kekuatan fleksural pada perendaman 24 jam lebih besar dibandingkan pada perendaman 48 jam, karena pada perendaman 48 jam waktu penyerapan alkohol dan air lebih lama dibandingkan dengan waktu perendaman 24 jam.

\section{SIMPULAN}

Berdasarkan hasil penelitian mengenai pengaruh kekuatan fleksural FRC dapat disimpulkan bahwa Lama perendaman E-glass fiber reinforced composite di dalam obat kumur berpengaruh terhadap penurunan kekuatan fleksural FRC.

\section{DAFTAR PUSTAKA}

1. Ballo, A.M., 2008, Fiber-Reinforced Composite as Oral Implant Material Expertimental Studies of Fiber Glass and Bioactive Glass In Vitro and Vivo, Turun Yliopisto, Turku, pp. 21-22.

2. Dahlan, M., 2011, Statistik untuk Kedokteran dan Kesehatan, Salemba Medika, Jakarta.

3. dos Santos, G., Marcos R.M., Carlos E.P.A., Jose C.R.R., dan Joao G.R.R, 2012, Flexural Strength of Composite Resin Light Cured with Different Exposure Modes and Immersed in Ethanol or Distilled water media. Journal of Consrvative Dentistry, 15(4):333-336.

4. Freilich, M.A., Meiers, J.C., Duncan, J.P., Goldberg, Eckrote, K.A., 2000, Fiber-Reinforced Composites in Clinical Dentistry, Quintessence Publishing Co. Inc. Illiois., pp. 1-56.
5. Mallick, P.K., 2007, Fiber Reinforced Composites Material, Manufacturing and Design, CRC Press, New York.

6. Mese A and Guzel KG., 2008, Effect of storage duration on the hardness and tensile bond strength of silicone- and acrylic resin-based resilient denture liners to a processed denture base acrylic resin, J Prosthet Dent. 99(2):153-9.

7. Miranda, C.E., Flavio, H., Debora, A., Jose, R.L., 2011, Effect of Mouthwashes on Knoop Hardness and Surface Roughness of Dental Composites Often Different Immersion Times, Departement of Restorative Dentistry, Brazil, pp. 168172.

8. Pantow, F.C., Krista, V.C., Damajanti H., 2015, Perbedaan Kekuatan Transversal Basis Resin Krilik Polimerisasi Panas pada Perendaman Minuman Berakohol dan Aquades, J. e-gigi, 3(2), hal. 2.

9. Porto, de Moraes., das Neves., de Souza C.K., Parolia, A., Barbosa dos Santos N., 2014, A Comparative Effect of Mouthwashes with Different Alcohol Concentrations on Surface Hardness, Sorption, Solubility of Composite Resins, OHDM, 13(2), pp. 502-6.

10. Zhang, M dan Matinlinna, J.P., 2011, E-glass Fibr Reinforced Composites in Dental Applicationa, Springer: Silicon, 42, pp. 73-78. Kaiser TM, Brinkmann G. Measuring dental wear equilibriumsthe use of industrial surface texture parameters to infer the diets of fossil mammals. Palaeogeogr Palaeoclimatol Palaeoecol. 2006;223. 